\title{
COMPLETE OPHTHALMOPLEGIA IN ACUTE TOXIC POLYNEURITIS*
}

\author{
BY \\ FRANK R. NEUBERT \\ Guernsey
}

Case Report

A well-developed, healthy country girl, aged 19 years, was delivered normally of her first baby on March 6, 1957.

Two days later her pupils began to dilate and she found she could not read. She had a vague history of epileptic fits and in view of certain domestic difficulties hysteria was suspected.

Examination.-On March 11 her eyes were found to be fixed in the primary position and no stimulus would cause her to move them; the pupils were immobile sensually and consensually to light stimulus and upon attempting accommodation. They contracted normally with pilocarpine. Accommodation was paralysed, corneal sensation was normal, and the lids moved normally. There was no nystagmus and no diplopia, and the fundi were normal.

Nothing abnormal was found in her general condition and an atypical attack of anterior poliomyelitis was suggested. The cerebrospinal fluid and blood picture were normal. The erythrocyte sedimentation rate was $4 \mathrm{~mm}$./hr.

Progress.-During the next few days her condition remained unchanged, but on one or two occasions fluids were regurgitated through the nose and she appeared to be less interested in her surroundings.

A throat swab showed no Klebs-Loeffler bacillus and a vaginal swab showed some diphtheroids which were non-pathogenic after an animal innoculation.

She complained of vague pains in the right shoulder and some ataxia was suspected, but her mental state was considered to be largely responsible for her condition.

She was given light pentothal anaesthesia in an attempt to obtain eye movements, to examine her reflexes, and to question her, but this failed.

On March 19 a repeat cerebrospinal fluid examination showed cells, less than 5 per cent. protein $300 \mathrm{mg}$., and a positive Nonne-Appelt test.

The next day she was transferred to a neuro-surgical unit on the mainland with the suggested diagnosis of a brain tumour, which appeared most unlikely, or anterior poliomyelitis. She was then found to have ophthalmoplegia, facial weakness, palatal palsy, ataxia, slight weakness of the upper arm muscles, and absent reflexes in all four limbs. It was found that the attack had been heralded by tingling in the hands and feet. The cerebrospinal fluid again showed an increase in protein and the diagnosis was made of an unusual variant of acute toxic polyneuritis.

Therapy.-She was treated with cortisone and recovery commenced; when the cortisone was discontinued there was a slight return of weakness of the deltoid muscles. Further treatment consisting of $300 \mathrm{mg}$. for 2 days followed by $100 \mathrm{mg}$. daily was given, and on April 4, 1957, she returned to Guernsey. She then had dilated and inactive pupils, full ocular movements, some nystagmus, a rapidly improving palate and face muscles, normal balance, and a feeling of wellbeing. She continued to improve steadily until normal health had been regained.

* Received for publication October 11, 1957. 


\section{Discussion}

This syndrome is not dealt with extensively in the ophthalmic literature. Rare ocular palsies in acute infective (rheumatic) polyneuritis are mentioned by Duke-Elder (1949):

Only in the rare event of a widespread lesion in the upper brain-stem, isolating the motor nuclei completely from all down-coming incitations and inhibitions and yet completely sparing them, does complete bilateral external ophthalmoplegia with the abolition of all movement result from supranuclear disturbances.

Price (1956) does not mention ophthalmoplegia in the section on polyneuritis, but Brain (1955) states that external ophthalmoplegia is occasionally seen, and also that dysphagia may occur, though the palate usually escapes.

Fisher (1957) reports three cases in each of which the cause of the syndrome was obscure until a great rise in cerebrospinal protein indicated a close relation to the Guillain-Barré type of polyneuropathy. Two of Fisher's cases had a total external ophthalmoplegia, but in one the preservation of downward movement was queried. In each of these the reaction of the pupil to light was sluggish, but in the case here reported there was no movement. In two of Fisher's cases there was moderate ptosis, and in one there was lid retraction. Apparently the ciliary body was not involved, for he does not mention the reactions of the pupil to accommodation or any alteration in the near point. Points of comparison between Fisher's cases and that here described are listed in the Table.

TABLE

\begin{tabular}{|c|c|c|c|c|c|c|c|c|c|c|c|c|}
\hline \multicolumn{2}{|l|}{ Case } & $\begin{array}{l}\text { Age } \\
\text { (yrs) }\end{array}$ & $\begin{array}{l}\text { Period of } \\
\text { Develop- } \\
\text { ment } \\
\text { (days) }\end{array}$ & \multicolumn{2}{|c|}{ Ophthalmoplegia } & Palate & $\begin{array}{l}\text { Pupillary } \\
\text { Reaction } \\
\text { to Light }\end{array}$ & Ptosis & Diplopia & Fundi & Ataxia & Recovery \\
\hline \multirow{3}{*}{ Fisher } & 1 & 45 & 4 & Total & $\begin{array}{l}\text { Not } \\
\text { mentioned }\end{array}$ & $\begin{array}{l}\text { Not } \\
\text { mentioned }\end{array}$ & Sluggish & $\begin{array}{l}\text { Moderate } \\
\text { retraction } \\
\text { of lids }\end{array}$ & Present & Normal & Severe & Good \\
\hline & 2 & 63 & 2 & Total & $\begin{array}{l}\text { Not } \\
\text { mentioned }\end{array}$ & $\begin{array}{l}\text { Not } \\
\text { mentioned }\end{array}$ & Sluggish & $\begin{array}{l}\text { Moderate } \\
\text { retraction } \\
\text { of lids }\end{array}$ & Absent & Normal & Severe & Complete \\
\hline & 3 & 63 & $5-6$ & $\begin{array}{l}\text { Query gaze } \\
\text { downward } \\
\text { preserved }\end{array}$ & $\begin{array}{l}\text { Not } \\
\text { mentioned }\end{array}$ & $\begin{array}{l}\text { Not } \\
\text { mentioned }\end{array}$ & Sluggish & $\begin{array}{l}\text { Moderate } \\
\text { retraction } \\
\text { of lids }\end{array}$ & Present & Normal & Severe & $\begin{array}{l}\text { Good } \\
\text { but mild } \\
\text { diplopia }\end{array}$ \\
\hline \multicolumn{2}{|c|}{ Neubert } & 19 & 2 & Total & Total & Palsy & None & $\begin{array}{l}\text { Lid move- } \\
\text { ments } \\
\text { normal }\end{array}$ & Absent & Normal & $\begin{array}{l}\text { In- } \\
\text { definite }\end{array}$ & Complete \\
\hline
\end{tabular}

I am indebted to Dr. W. B. Fox for permission to report this case and for allowing access to his notes, and to Dr. G. S. Graveson for his report on the patient from the mainland and for his reference to Fisher's paper.

\section{REFERENCES}

Brain, Russell (1955). " “Diseases of the Nervous System”, 5th ed. Oxford University Press, London.

DUKe-ElDER, S. (1949). "Text-book of Ophthalmology", vol. 4, p. 4105. Kimpton, London. FISHER, M. (1957). New Engl. J. Med., 255, 57.

PRICE, F. W. (1956). "Text-book of the Practice of Medicine", 9th ed. Oxford University Press, London. 